\title{
Canon Formation, Library Collections, and the Dilemma of Collection Development
}

\section{Mark Cyzyk}

The purpose of this article is to conceptually clarify the precise function and duties of the collection development officer. In so doing, the relevance of current literary research surrounding canon formation to collection development is suggested. Methods of collection evaluation and development are discussed and shown to be intimately tied to existing canons of research materials/interests. The fact that canons are in flux, and that traditional collection development strategies attempt to anchor themselves in such protean entities, results in a dilemma for the collection development world. On the one hand, collections must be aimed at satisfying the needs of the current user group. On the other hand, the collection development officer has a more cosmopolitan duty to collect items that are not currently of interest or do not directly relate to what is currently deemed canonical, yet may become so in the future. With such a precarious professional position in mind, various strategies for a solution to the dilemma are sketched.

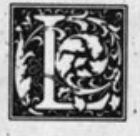

ibrarians, and particularly collection development officers, can learn a lot from recent literary research in canons and canon formation. The findings of this research are relevant to the self-conception of collection development and to the general function of the library. The purpose of this paper is to discuss in broad terms (1) the notion of canon formation and evolution, (2) its importance with regard to collection development (essentially, to draw out the connection between the canon as collection development officers find it-readymade - and the theoretical foundations of collection development), (3) to survey the main instruments of collection evaluation and development, and assess how well they contribute to adequate collection develop- ment in what will be referred to as temporally parochial or cosmopolitan terms, and (4) to show how the dilemma of collection developmentarises through the conflict of present-day literature with the possibility of future disparate canons.

\section{DEFINING CANON FORMATION}

The traditional conception of the canon-one that quite recently was brought to the fore and championed, for instance, by Allan Bloom in The Closing of the American Mind-is that the literary canon represents the best in what has been written throughout history. It is assumed that scientific canons are included as well, though they are less problematic than literary canons because they are not as value-laden or as susceptible to blatantly

Mark Cyzyk is Assistant Librarian at Capitol College, Laurel, Maryland 20708. The author wishes to express his gratitude for helpful criticism received from the anonymous reviewers of this journal as well as from John V. Antinori, former Editorial Assistant of C\&RL. 
subjective influences as are literary canons.' Such a view, however, presupposes a thorough absolutism or objectivism in regard to the value of a work. Indeed, such a view presupposes that the classic controversy endemic to theories of value-namely, the conflict between absolute and relativistic theories of value-has been solved in favor of the absolutist/objectivist position. But the controversy has not been patently settled and has begun to lean favorably in the past century toward a relativistic stance. ${ }^{2}$

Essentially, the relativist challenge to the traditional concept of the canon is that instead of a single, absolute realm of value that can somehow be referenced and held as a standard for all works, there are several standards of value, each perhaps incommensurate with the rest, relative to which a work is judged. Therefore, a work judged to be exemplary by one set of standards, and admitted into the formal canon of that particular tradition may be wholly unacceptable in another. It may be totally inappropriate, for instance, to judge a work of contemporary Balinese literature against the standard of the Western tradition (the traditional conception of that tradition, that is). Likewise, what may be considered to be an excellent piece of literature by American standards may be judged a mediocre piece of literature by the Kenyans. Cultural differences are not the only factors figuring into the formation of a canon or tradition. Historical contexts are equally as important. Therefore, what may have once been judged to be a superlative, valuable work within a tradition, may at another time, and within the same tradition, be judged quite differently. Judgments often change, though it is hoped, not abruptly, and so, too, do the traditions which support and validate those judgments. The above explanation is a gross simplification of the relativist position, for it blatantly ignores the fact that there are several varieties of relativistic theory. Nevertheless, it should provide sufficient background for what follows.

\section{LITERARY RESEARCH ON CANONS}

Much of the work in literary research about the problems posed by canons can be summed up as research attempting to either (1) prove that the absolutist's sense of value does not account for the way canons work (with regard to their selective inclusion and exclusion of particular works or bodies of works), or (2) discover and describe the mechanisms responsible for the sometimes radical evolution of various established canons. With respect to the first of these goals, and specifically against the absolutist tenet that canons are composed of items that have been disinterestedly judged to be the best, literary theorist Charles Altieri contends: "Canons are simply ideological banners for social groups: social groups propose them as forms of self-definition, and they engage other proponents to test limitations while exposing the contradictions and incapacities of competing groups." ${ }^{3}$ Barbara Herrnstein Smith promotes this same claim by noting: "As is often remarked, since those with cultural power [those, like editors, who determine what will and will not be published in the first place] tend to be members of socially, economically, and politically established classes (or to serve them and identify their own interests with theirs), the texts that survive will tend to be those that appear to reflect and reinforce establishment ideologies." ${ }^{\prime 4}$ With respect to the second abovementioned goal, Herrnstein Smith further remarks:

[T] he repeated inclusion of a particular work in literary anthologies not only promotes the value of that work but goes some distance toward creating its value, as does also its repeated appearance on reading lists or its frequent citation or quotation by professors, scholars, and academic critics. For all these acts, at the least, have the effect of drawing the work into the orbit of attention of a population of potential readers; and, by making it more accessible to the interests of those readers (while.... at the same time shaping and supplying the very interests in relation to which they will experience the work), they make it more likely both that the work will be experienced at all and also that it will be experienced as valuable. ${ }^{5}$ 
Such statements by Herrnstein Smith and others are intended to illustrate how social and political mechanisms are in some sense responsible for the formation and evolution of canons. ${ }^{6}$ They show that the Enlightenment goal of disinterested judgment is a mere phantasm. Against the traditional conception of the canon, the contemporary fashion is to maintain that the cream does not, solely on its own merit, rise to the top. The worth of a work is insidiously, fundamentally, socially, and historically mediated. ${ }^{7}$

\section{COLLECTION DEVELOPMENT}

Such a relativistic stance regarding how canons are formed and evolve, if accepted, has profound importance for the self-conception of the goals and purposes of library collection development. The development of library collections is quite different, in one sense, from the development of a canon of superlative literature. Even though the minimal responsibility for the library world is to collect books that have been granted the privileged status of canonical work, many libraries also collect works considered marginal or unacceptable to the established canon. Yet it is possible that the very mechanisms which supported the evolution of canons-namely, the social and ideological mechanisms involved in the publishing and promotions process-also hold true for library collection development. In the following pages it will be shown how the instruments currently employed for evaluating and developing library collections work within and support this larger process. ${ }^{8}$

F. W. Lancaster has identified the following three ways in which collections can be evaluated:

1. The subjective evaluation of parts of the collection by subject specialists. In this impressionistic approach, the subject specialists become, in a sense, an external standard against which the collection is measured.

2. Checking all or part of the collection against some type of list that is accepted as the external standard. The list may already exist (e.g., the holdings of another library pre- sumed to be especially strong in a particular subject) or it may be prepared especially for the evaluation.

3. Evaluating the collection in terms of the volume and type of use it is receiving or has received in the immediate past. 9

It is easy to see how the first of these three types of collection evaluation works within and supports the structure of an existing canon: any subject specialist is, at once, both a product of and a contributor or potential contributor to the established canon. The specialist has some form of expertise with regard to the canon or segment of the canon of works deemed exemplary. It is against this backdrop that the specialist evaluates any library collection.

Likewise, the second type of evaluation works entirely within and supports the valued status of an existing canon of literature. Good examples of this include use of the Research Library Group (RLG) Conspectus and the Lopez Method or Citation Technique of evaluating collections. Both are primarily methods for evaluating collections, but because evaluation often results in altered development policies, both, in a sense, are also development tools. The famed RLG Conspectus serves as a union list of the collections of several major North American research libraries. It is a list against which individual institutions check their collections. ${ }^{10}$ Each institution on the list is assigned a level of collecting intensity for particular subjects so that a collection cooperative is formed. The cooperative allows a library to collect a large number of works most in demand by the local user group while maintaining access from other libraries to research material that is not widely in demand on the local level. This allows the needs of each participating institution to be met without the financial burden of having to collect at higher intensities those materials not generally demanded by the local user group. The result of this process, with respect to canons, is that only materials in the subjects demanded by the local user groups of the particular library are collected at the highest intensities. Only 
items falling into the traditional canon of subjects as determined by a consensus of the academic user group as a whole are pursued for collection as a whole at the highest intensities. At no point does such vigorous collection development proceed outside of the consensually agreed-upon canon of topics. Consequently, use of the RLG Conspectus works clearly within the confines of what is deemed by users to be of legitimate research interest, and hence, of the items that are at least candidates for canonical status. These are items that have been socially and historically projected, in Herrnstein Smith's idiom, into the orbit of attention of current and future user groups. This is not to say that certain subjects are entirely neglected. Materials on Milton scholarship, for instance, may be collected at higher general intensities throughout the library world than others, such as works on feminist film theory, because they are more historically entrenched topics of scholarship. But there are select institutions collecting materials on feminist film theory at equivalent or higher intensities than those on Milton scholarship.

\section{We are historically situated in the only place ideal for collecting and preserving the artifacts of the present state of society. But our responsibility seems to transcend the satisfaction of the needs of the present members of that society. For whose society should we collect?}

The Lopez or Citation Technique of evaluation also works within and supports the existing canon of literature." This technique consists primarily of checking the citations of a random list of journal articles against the collection to determine if the collection contains those items. This procedure is performed for several iterations. The results for each iteration are assigned quantifiable weights. The results are added up to obtain a numerical value for the performance of the collection. What is of importance for the purposes of this article is that, even more than the RLG Conspectus, the Lopez Method relies upon the existing canon of journal articles and the current interests of academics to determine what will be of lasting importance and what will be included in the collection. The third type of collection evaluation clearly follows the same tack and, therefore, need not be discussed.

These three types of collection evaluation have one thing in common: a conception of what it is that a collection is supposed to accomplish. Each views the collection as a function of current user needs, even though some stress the term current more than others. But this brings us to the following question: Is the goal of collection development merely to collect all works of importance, both the good and the bad, that a particular society has to offer within a particular temporal framework? The resulting collection, assuming it is possible to collect materials in all areas of research interest to that particular society within a particular temporal framework, would be representative merely of the self-conception of that particular society within that particular historical context. Future research may require materials reflecting not a particular self-conception of a society at a given moment in its evolution but, instead, materials reflecting the context within which such self-conceptions are made. The materials necessary for determining this may or may not be collected and maintained. Concern for materials reflecting the self-conception of the current state of society is essentially what the collection evaluation and development strategies sketched above currently focus upon. The very instruments employed in the development and evaluation of library collections are geared toward such goals. But isn't it the collection development officer's duty to collect with a view to future user groups, as well as a view of the needs of the current user group? Should the activities of the collection development officer be dictated solely by the societal and historical parochialism of the current user group? Should collection development be a function of the current canon, a canon whose authority has widely been challenged in recent years? ${ }^{12}$ 
If these two conceptions of the duty of collection development are taken seriously, the result is a dilemma for collection development.

\section{THE DILEMMA OF COLLECTION DEVELOPMENT}

A dilemma is essentially a logical construct wherein two mutually exclusive and equally truthful claims compete for acceptance. By this definition, collection development faces a dilemma. The dual duties of the collection development officer are important in their own right, are mutually exclusive (at least in their purest forms), and compete for the attention and financial resources of the individual collection development officer and the entire library world.

The dual duties of the collection development officer are important in their own right, are mutually exclusive (at least in their purest forms), and compete for the attention and financial resources of the individual collection development officer and the entire library world.

The most easily identifiable manifestation of this dilemma is the notion of lost works, which recurs throughout history and historical scholarship. The works of Aristotle, for example, were lost until the Middle Ages. However, through citations from other sources, scholars knew all along that Aristotle's works existed. Aristotle's dialogues remain lost even today, yet we know that he wrote dialogues in the Platonic tradition. One can only surmise how important these documents would be to both past and current scholarship if they had survived. More important, though, is the question of what would have happened if the dialogues were not collected and maintained by a library because they were not thought at the time to have been of any value. This is almost certainly a counterfactual explanation of the loss of his works but nevertheless an interesting one to consider in the context of this article. Given such a supposition, the dilemma for collection development is made clear: For whom should we collect? We are historically situated in the only place ideal for collecting and preserving the artifacts of the present state of society. But our responsibility seems to transcend the satisfaction of the needs of the present members of that society. For whose society should we collect?

The loss of the works of lesser known writers is also an issue. It must be kept in mind that, as was maintained by the relativistic theorists of canon formation, authors are evaluated against an existing canon. Canons, like societies, have a tendency to evolve, so a judgment regarding the work of an author made at one time in history may be quite different from one made at another time. James Hulbert illustrates this point in his discussion of the writings of the Marquis de Sade, the eighteenth-century suppression of those writings, and the twentieth-century rediscovery and slow legitimization of them asitems worthy of scholarly attention. ${ }^{13}$ The dilemma is made manifest when it is realized that de Sade's work may actually have been destroyed (much of it was, in fact) in the eighteenth century and, as such, would not have survived to prompt a twentieth-century rediscovery. How many past writings of now current value have been doomed to bibliographic oblivion because they simply were not collected and maintained by libraries to await rediscovery?

The net effect of the collection development officer's neglect of the cosmopolitan side of his dual duties is that the collection of any particular period suffer a blind spot in their coverage. The collection development officer is faced with a dilemma and, more often than not, adopts the parochial duty as the prime concern and responsibility. Such a choice is not difficult to sympathize with, however, since it is upon the current users and the current interests of the current society that the library world relies for its economic sustenance and survival.

In the end, collection development officers play out their roles amid the tension between their theoretic function 
and the realities of economic constraint. This tension is heightened by the further epistemological constraint to which collection development officers are subject: They cannot jump outside of their sociohistorical situation to know what will be of research interest in the future. Based on the unsteady premise that the canon of future research interest will closely resemble that of the past and of the present, collection development officers can, at best, hope to predict-not calculate-the needs of the future. Such attempts at prediction always involve somewhat of an irrational leap from the actual needs of current users to the merely possible needs of future users.

\section{WHAT CAN BE DONE?}

In an effort to stave off the disillusionment such conclusions may prompt, it should be pointed out that librarians can go some way toward successful prediction of and provision for future research needs. Librarians can, in many instances, minimize the uncertainty of their choices for collection and maximize the probabilities that their choices will indeed match the needs of a future user group.

Paul Metz and Bela Foltin, Jr. make several interesting points in this regard. They suggest that nondisciplinary areas (areas which have been referred to in this paper as falling outside the traditional canon of subjects) and interdisciplinary areas (areas that may be in the process of canonization) should be paid special attention when selecting materials. A good example, and enunciation of the need for active collection in noncanonical areas, is the more popular naturalist and travel genres which Metz and Foltin stress may be of use, perhaps canonized, in the future. The naturalist writings of Edwin Way Teale and the travel books of Paul Theroux are examples. ${ }^{14}$ With regard to nonacademic prose, Metz and Foltin note:

The highly intelligent lay essay is a culturally important contribution, examples of which often attract academic attention in later years. In considering such materials, selectors should ask themselves whether their policies would support the acquisition of T. E. Lawrence's
Seven Pillars of Wisdom or George Orwell's Homage to Catalonia if these unquestioned masterpieces describing war and the politics of war were written today. ${ }^{15}$

In short, by acting in accordance with the knowledge gained through a careful consideration of the evolution of canons, librarians can perhaps maximize the probability that items chosen for inclusion in collections today, while presently of marginal or no value, will be of use tomorrow.

In the end, collection development officers play out their roles amid the tension between their theoretic function and the realities of economic constraint.

Metz and Foltin's suggestions are, however, aimed at improving the comprehensiveness of the collections of individual institutions, not at improving the comprehensiveness with which bibliographic materials are collected throughout the library world as a whole. But Metz and Foltin, through their suggestions for improving the geographically specific collection, have indeed hinted at a way in which bibliographic coverage in toto can be enhanced. What the library profession as a whole must do is to critically consider what genres, formats, and subject areas - regardless of current user interest or support-are not currently being collected.Such critical scrutiny would give the collection development community a clearer picture of what is presently being allowed to fall by the bibliographic wayside. Based on such knowledge, the library world would be able to form some type of union for special collections perhaps modeled after the organizational framework surrounding the RLG Conspectus. ${ }^{16}$ Such a union would consist of member institutions who take their temporally cosmopolitan responsibilities for collection development seriously and seek to pursue and maintain collections of materials that are of minimal or no interest to current researchers. ${ }^{17}$ Representative 
materials may include formats and genres such as comic books and pornography, which are items that are being collected by a few academic libraries but could probably be more efficiently collected and maintained if a union of institutions was formed. ${ }^{18}$ In this manner, librarians can rationally address their responsibilities for the future.

The purpose of this article is to draw out the connection between the protean canons of literature and of topics of research, and the collection development re- sponsibilities of the library world. If the dual duties suggested for collection development are accepted, the collection development officer becomes entangled in a dilemma. As such, the officer is caught in the unenviable position of either neglecting his or her duty to collect materials that may prove to be of possible interest for future research, or taking the leap of deciding to collect such items. Collecting such items, however, could be to the detriment of collections of materials known to be of at least minimal use to current research.

\section{REFERENCES AND NOTES}

1. Scientific canons are not as problematic as are canons in the humanities because they are repeatedly legitimized through their usefulness. Their value lies in pointing the reader toward an interpretation of the world that allows that reader to successfully predict and thus manipulate the workings of the physical world. Scientific work is not canonized unless it results in these relatively easily recognizable results.

See, for example, the work of Thomas Kuhn for relevant discussion regarding the canonicity of scientific practices and programs. What this article refers to as a scientific canon is basically equivalent to Kuhn's notion of a body of exemplars within a disciplinary matrix. See his "Second Thoughts on Paradigms," in The Essential Tension: Selected Studies in Scientific Tradition and Change, (Chicago: Univ. of Chicago Pr., 1977), 293-319.

2. For a survey of these disputes and an attempt to transcend them, see Richard Bernstein, Beyond Objectivism and Relativism: Science, Hermeneutics, and Praxis, (Philadelphia: Univ. of Pennsylvania Pr., 1983).

3. Robert von Hallberg, ed., Canons (Chicago: Univ. of Chicago Pr., 1984), 43.

4. Ibid, p.34. Barbara Herrnstein Smith notes that this is generally the case. Works such as folktales and proverbs survive outside the formal literary canon, but often are considered substandard (which indeed they are, when judged relative to works within the canon) and antiestablishment.

5. Ibid., 29.

6. For an interesting account of the evolution of the American poetry canon-an account that perfectly illustrates the points made above-see Alan C. Golding, "A History of American Poetry Anthologies," in Canons, 279-307; for other relevent comments see James Hulbert, "The Problem of Canon Formation and the 'Example' of Sade: Orthodox Exclusion and Orthodox Inclusion," Modern Language Studies 18(Winter 1988):120-33; Arnold Krupat, "Native American Literature and the Canon," in Canons, 309-35; Lawrence Lipking, "Aristotle's Sister: A Poetics of Abandonment," in Canons, 85-105; and Richard Ohmann, "The Shaping of a Canon: U.S. Fiction, 1960-1975," in Canons, 377-401.

7. Christopher Ricks, "What Is at Stake in The 'Battle of the Books'?" New Criterion 8(Sept. 1989):40-44. Ricks recently and eloquently argued against this now widespread view. $\mathrm{He}$ insisted that some authors are patently better than others, and maintained that it is the fecund character of a work-its ability to inspire future authors-that is the distinguishing characteristic of exemplary works. It is a characteristic, Ricks would stress, that is inherent in the work:

No one is ever going to be absolved from the necessity of distinguishing responsibly between that which is established because it has been found true and that which is found true because it has become established. Injustices have-cannot but haveoccurred or excluded certain writers (though not only for reasons of color, gender, or class), but it is true too that there are writers, past and present, who are not 'marginalized' but marginal. (40-41) 
The crucial constituting of what is tenditiously called the canon is effected not by academics and critics but by creative writers (the obscuring of the distinction having therefore been for some time a trade-union necessity for professors), and the crux is the conviction that works of literature must live, not in the formation of the cunning canon or the candid curriculum, but in their fecundating of later works of literature. (44)

Ricks seems to miss the point in this second passage; if a work of literature can inspire a future author, and thus is deemed a valuable work, such a view presupposes that that work has somehow come to the attention of the future author. It is this "somehow," this mediating process, which interests the theorists discussed in the body of this paper and which Ricks skillfully glosses over. His sympathy in the first passage is somewhat disarming, and the problem of how a relativist can manage to make value judgments and claim them to be valid value judgments is a problem that can only be worked out by a large-scale, relativistic, axiological theory. That is an undertaking well beyond the scope of this paper.

8. It is the view of the author that the evaluation of collections and the development of collections are so closely bound, practically and conceptually, that to constantly refer to them in the same breath does not risk conflation, but somewhat alleviates the unwieldiness of an almost false distinction.

9. F. W. Lancaster, "Evaluating Collections by Their Use," Collection Management 4(Spring/Summer 1982):15.

10. See Nancy E. Gwinn and Paul H. Mosher, "Coordinating Collection Development: The RLG Conspectus," College \& Research Libraries 44(Mar. 1983):1; and Anthony W. Ferguson et al., "The RLG Conspectus: Its Uses and Benefits," College \& Research Libraries 49(May 1988):198-206.

11. Manuel D. Lopez, "The Lopez or Citation Technique of In-Depth Collection Evaluation Explicated," College \& Research Libraries 44(May 1983):251-55.

12. For a critique of library ideology and practice in this regard, see Michael $\mathrm{H}$. Harris, "State, Class, and Cultural Reproduction: Toward a Theory of Library Service in the United States," Advances In Librarianship, vol.14., Wesley Simonton, ed. (San Diego: Academic, 1986), 211-52.

13. Hulbert, "The Problem of Canon Formation and the 'Example' of Sade: Orthodox Exclusion and Orthodox Inclusion," 120-33.

14. Of particular note in this respect is the existence of a substantial underground press in this country. For an interesting account and survey of underground fictionists, see Robert Siegle, Suburban Ambush: Downtown Writing and the Fiction of Insurgency, (Baltimore: Johns Hopkins Univ. Pr., 1989).

15. Paul Metz and Bela Foltin, Jr., "A Social History of Madness-or, Who's Buying This Round? Anticipating and Avoiding Gaps in Collection Development," College $\&$ Research Libraries 51(Jan. 1990):36-37.

16. Rebecca R. Martin hints at this in her "Special Collections: Strategies for Support in an Era of Limited Resources," College and Research Libraries 48(May 1987):241-46.

17. The current vogue for research in social history attests to the fact that, in many instances, bibliographic artifacts not thought to be valuable enough to warrant collection and maintenance by those populating one segment in a society's evolution (namely, the segment contemporary with the production of the specified items) become the invaluable research resources for another temporally distinct segment of that same society. For commentary in this regard, see William A. Joycy, "The Evolution of the Concept of Special Collections in American Research Libraries," Rare Books and Manuscripts Librarianship 3(Spring 1988):19-29. An organized union of special collections could somewhat resolve this problem - a problem which, if artifacts of a solely bibliographic nature are concerned-falls uniquely to the library world to solve.

18. See Subject Collections, 6th ed., comp. Lee Ash, (New York: Bowker, 1985). It lists twenty-two major collections of comic books and three major collections of pornographic material (the largest of which is housed at Indiana University). 


\section{New from Greenwood Publishing Group}

\section{AUTOMATED INFORMATION RETRIEVAL IN LIBRARIES}

A Management Handbook

By Vicki Anders

Managers of automated information retrieval services will find in this book practical advice for managing an integrated service. The book is unique in that it looks at the various methods of delivering automated information retrieval services as part of an integrated unit.

Greenwood Press. 1992. 264 pages. 0-313-27361-8. $\$ 55.00$.

\section{CIRCULATION SERVICES IN A SMALL ACADEMIC LIBRARY} By Connie Battaile

Battaile provides a detailed volume written for those new to the circulation department of small academic libraries. She presents not the definitive way to run a circulation department, but rather she provides a variety of possible methods.

Greenwood Press. 1992. 224 pages. 0-313-28126-2. $\$ 45.00$.

\section{PLANNING IN THE UNIVERSITY LIBRARY}

By Stanton F. Biddle

Analysis of academic library planning procedures and how major libraries have been responsive to changes over the past several decades. Greenwood Press. 1992. 238 pages. 0-313-27788-5. $\$ 47.95$.

\section{THE LIBRARY AND ITS USERS The Communication Process By John M. Budd}

The purpose of this book is to examine the library and the librarian as they communicate with their patrons. Drawing from several literatures, Budd furthers the discussion of this communication process. Greenwood Press. 1992. 216 pages. 0-313-28153-X. $\$ 39.95$.

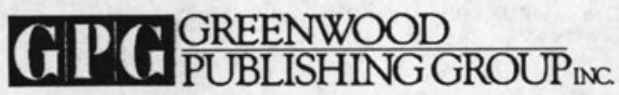

\section{USING CONSULTANTS \\ IN LIBRARIES AND INFORMATION CENTERS A Management Handbook Edited by Edward D. Garten}

A handbook offering practical guidance in selecting and using consultants in libraries and information centers. This handbook offers a comprehensive discussion of the consultant/library relationship. Greenwood Press. 1992. 304 pages. 0-313-27878-4. $\$ 49.95$.

\section{HANDBOOK OF ACADEMIC ADVISING \\ By Virginia N. Gordon}

This comprehensive professional reference overviews the academic advising concerns of both administrators and practitioners. It takes a thoughtful look at the history, meaning, and development of academic advising and considers many of the issues fundamental to the effective delivery of advising services. Greenwood Press. 1992. 224 pages. 0-313-28458-X. $\$ 49.95$.

\section{BRITISH ENGLISH FOR AMERICAN READERS}

A Dictionary of the Language, Customs, and Places of British Life and Literature By David Grote

"For Americans facing British culture in books, on TV, or in media, this dictionary really fills a void. What is bubble and squeek? How do you roger? Who is a Yob?... This dictionary answers questions like these and more that our American dictionaries of the English language don't. It's also great fun to read for no reason at all. Recommended for most collections." Library Journal Greenwood Press. 1992. 728 pages. 0-313-27851-2. $\$ 85.00$.

\section{PUBLISH, DON'T PERISH}

The Scholar's Guide to Academic Writing and Publishing

By Joseph M. Moxley

This book offers informed suggestions to faculty members for conceiving, developing, and publishing scholarly documents as books or journal articles. Moxley also addresses political and economic factors that impinge on what is written and published.

Greenwood Press. 1992. 224 pages. 0-313-27735-4. $\$ 35.00$.

\author{
88 Post Road West, Box 5007, \\ Westport, CT 06881
} (203) 226-3571 Fax (203) 222-1502 